$10-2005$

\title{
Forging a Multilayered System of Global Governance
}

Charlotte Ku

Texas A\&M University School of Law, cku@law.tamu.edu

Follow this and additional works at: https://scholarship.law.tamu.edu/facscholar

Part of the International Law Commons

\section{Recommended Citation}

Charlotte Ku, Forging a Multilayered System of Global Governance, in Towards World Constitutionalism 631 (Ronald St. John MacDonald \& Douglas M. Johnston eds., 2005).

Available at: https://scholarship.law.tamu.edu/facscholar/845

This Book Section is brought to you for free and open access by Texas A\&M Law Scholarship. It has been accepted for inclusion in Faculty Scholarship by an authorized administrator of Texas A\&M Law Scholarship. For more information, please contact aretteen@law.tamu.edu. 


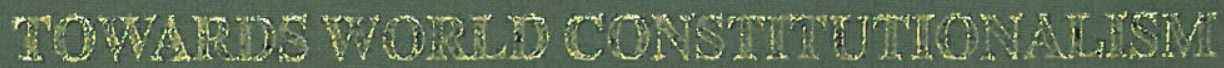

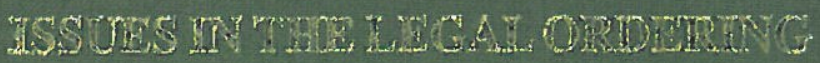

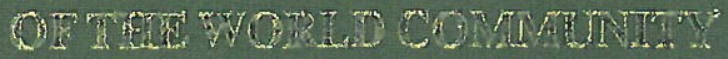

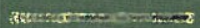

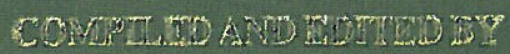

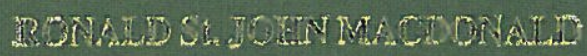 \\ AND

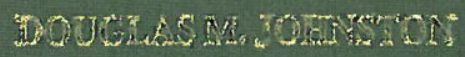

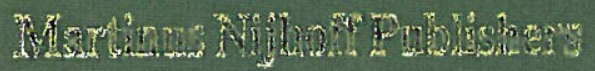




\title{
23. Forging a Multilayered System of Global Governance*
}

\author{
Charlotte Ku
}

\section{Introduction: International Law's Challenge to Global Governance}

The 1648 Peace of Westphalia marked the beginning of the system of sovereign states that remains a part of global governance today. By opting for this voluntarist system more than 300 years ago, the major powers of the day rejected a "juridical order founded on a common respect for law" in favor of a system where law operated "between rather than above states." International lawyers have worked for centuries to move the international system to one of an order based on a common respect for law, and have made great progress. Indeed, the twentieth century surely will be remembered as one of the most significant in the development of international law.

During the twentieth century:

- The coverage of international law expanded to embrace both new subject matters and forms of interaction. Issues are no longer exclusively local or global, they are now often both. ${ }^{2}$

- The players in international law expanded both in numbers and types with the number of states tripling and private entities like corporations and nongovernmental organizations gaining prominence as recognized international actors.

- The volume and pace of cross-border activity has increased.

* Portions of this chapter are drawn from Charlotte Ku, Global Governance and the Changing Face of International Law, 2001 John W. Holmes Memorial Lecture (Academic Council on the United Nations System: ACUNS Reports \& Papers, 2001) and Charlotte Ku, "When Can Nations Go to War? Politics and Change in the UN Security System," 24 Michigan Journal of International Law (Summer 2003), pp. 1077-1120.

1 See Leo Gross, "The Peace of Westhpalia, 1648-1948," 42 American Journal of International Law (1948), p. 29.

2 See David Held, "From Executive to Cosmopolitan Multilateralism," in Taming Globalization: Frontiers of Governance," edited by David Held and Mathias Koenig-Archibugi (Cambridge, UK: Polity Press, 2003), p. 162. 
- The standards of international behavior particularly in the treatment of individuals have changed so that states now ignore human rights standards at some cost to their international reputation. Although inconsistently applied as happened in Rwanda, if the violations are widespread enough, states may even risk war to correct the perceived transgression as happened in the former Yugoslavia.

A major contributing factor to this horizontal expansion has been the increased number of private actors entering into the public sphere. As an academic subject, much pioneering work to draw attention to this phenomenon of shifting boundaries can be linked to feminist scholarship that sought to raise awareness of the experience of women whose lack of public status and identity often precluded pursuit of their individual rights and the political engagement to correct that. ${ }^{3}$ Another area that encouraged thinking about the relationship between the public and the private is in the area of international economic and trade law. ${ }^{4}$ The public/private relationship that needed a basis for operation was in dispute settlement where the investment and trade agreements would be made by states, but the disputes often occurred between private corporations and the public authorities in the countries where trade or investment was taking place. Such innovations as the International Centre for the Settlement of Investment Disputes were created so that private parties could directly pursue a dispute against a state to resolve issues arising from investments.

In like manner, we have seen a vertical development where the international and the national systems of governance are converging to perform legislative and administrative functions for international law. This occurs because:

- of the limited capacities of international institutions;

- of the more developed institutional, political and legal processes that are available at the national level; and

- working within a less institutionalized international framework can provide the opportunity for cooperation and coordination without developing a hierarchy that may make such cooperation more politically costly for states. ${ }^{5}$

Ensuring that the elements of such a mixed system of governance remain appropriately synchronized to support international law is the challenge that these developments have created. Taken individually, each of the developments listed above could be seen as a positive development. It is the cumulative effect of these developments that may be responsible for a sense of system-wide stress and dysfunction causing some to wonder if we are heading into a "World of Disorder."

See Hilary Charlesworth and Christine Chinkin, The Boundaries of International Law: A Feminist Analysis (Manchester: Manchester University Press, 2000).

See, for example, Ronald A. Brand, "Sovereignty: The State, the Individual, and the International Legal System in the Twenty First Century," 25 Hastings International and Comparative Law Review (Summer 2002).

Anne-Marie Slaughter, "Courting the World," Foreign Policy (March-April 2004), p. 79.

6 See ASIL 2005 Annual Meeting Theme Statement, "New World Order or World in Disorder? Testing the Limits of International Law," available at www.asil.org. 
In a 2001 lecture titled "Global Governance and the Changing Face of International Law," I observed that one of the enduring themes of international relations was expansion and diffusion. I further remarked that "[h]ow well international law has expanded its framework to address this diffusion is a key test of international law's relevance to global governance questions in the future." In fact what we seem to be witnessing since the mid-twentieth century is normative growth without a related increase in the capacity of international institutions and frameworks to implement these norms. What has therefore resulted is something of a potpourri approach to governance where ad hoc partnerships may be formed to perform functions that the formal institutions seem unable to carry out either effectively or adequately. And what adds to the complexity of understanding governance today is that those playing important governance roles are no longer exclusively from the public sector, but also increasingly from the private sector. David Held described this situation:

... [W]e live with a challenging paradox - that governance is becoming increasingly a multilevel, intricately institutionalized and spatially dispersed activity, while representation, loyalty and identity remain stubbornly rooted in traditional ethnic, regional and national communities. ${ }^{8}$

The number of governance elements in question today can be potentially destabilizing because of the number of possible disconnects among them. Or as Robert Keohane observed: "Since there is no global government, global governance involves strategic interactions among entities that are not arranged in formal hierarchies. Since there is no global constitution, the entities that wield power and make rules are often not authorized to do so by general agreement." 9 Such a multilevel system could work, but only if it has adequate capacity to govern effectively and if all elements at all levels are willing to cooperate. The role of states has therefore also changed from being one of problem solving to one of interdependence manager. ${ }^{10}$ Working towards a juridical order with a common respect for law could provide all these elements with common purpose and direction to enhance coordination and to contribute to a generally stable governing structure. But accomplishing this may require a fundamentally changed view of world order where states remain major actors, but where the

7 Charlotte $\mathrm{Ku}$, "Global Governance and the Changing Face of International Law," 2001 John W. Holmes Lecture, ACUNS Reports and Papers 2001 No. 2 (Academic Council on the United Nations System: 2001), p. 7.

8 David Held, "From Executive to Cosmopolitan Multilateralism," in Taming Globalization: Frontiers of Governance, edited by David Held and Mathias Koenig-Archibugi (Cambridge, UK: Polity Press, 2003), p. 166.

9 Robert O. Keohane, "Global Governance and Democratic Accountability," in Taming Globalization: Frontiers of Governance, edited by David Held and Mathias KoenigArchibugi (Cambridge, UK: Polity Press, 2003), p. 131-2.

10 Paul Kennedy, Dirk Messner, and Franz Nuscheler, eds. Global Trends \& Global Governance (London: Pluto Press, 2002), p. 59. 
supplements to state authority and capacity may come from a wider pool of public and private institutions at both the international and national levels.

\section{Strategic Interactions to Bolster Governance}

Looking into the future at the end of the twentieth century, Louis Henkin wrote that the world was moving away from an emphasis on state values to a growing concern for human values.

State autonomy remains a powerful value, but the distinction between state and human values continues to converge. The right of a state "to be let alone" subsumes the rights of its inhabitants to be let alone, to maintain their traditions and culture, as well as their ways of life. ${ }^{11}$

Table 1 shows the growth in multilateral treaty activity in the areas of human rights and more broadly in human welfare over 300 years of treaty activity. (Human welfare includes items like health and food safety that do not fall directly under human rights and are included in the table as "Other Human Welfare.") Although increasing in numbers, multilateral treaties that address human rights and human welfare still generally account for less than $15 \%$ of overall multilateral treaty activity.

Table 1: Multilateral Treaty Subjects by Period 1648-1995 $5^{12}$

\begin{tabular}{|c|c|c|c|c|c|c|c|c|c|c|c|c|c|c|}
\hline & \multicolumn{2}{|c|}{$1648-1750$} & \multicolumn{2}{|c|}{$1751-1850$} & \multicolumn{2}{|c|}{$1851-1899$} & \multicolumn{2}{|c|}{$1900-1925$} & \multicolumn{2}{|c|}{$1926-1950$} & \multicolumn{2}{|c|}{ 1951-1975 } & \multicolumn{2}{|c|}{ 1976-1995 } \\
\hline & & & $\#$ & $\%$ & \# & $\%$ & $\#$ & $\%$ & \# & $\%$ & $\#$ & $\%$ & \# & $\%$ \\
\hline $\begin{array}{l}\text { Political/ } \\
\text { Diplomatic }\end{array}$ & 72 & 84 & 64 & 64 & 162 & 48.0 & 249 & 38 & 292 & 25 & 508 & 25 & 315 & 19 \\
\hline Military & 13 & 18 & 8 & 8 & 17 & 8.0 & 55 & 8 & 99 & 8 & 80 & 4 & 59 & 4 \\
\hline Economic & 1 & 1 & 13 & 13 & 143 & 42.0 & 241 & 36 & 546 & 46 & 885 & 43 & 719 & 44 \\
\hline $\begin{array}{l}\text { Human } \\
\text { Welfare }\end{array}$ & & & 13 & 13 & 11 & 3.0 & 68 & 10 & 144 & 12 & 158 & 8 & 111 & 7 \\
\hline Cuiltural & & & 1 & 1 & & & 7 & 1 & 17 & 1 & 34 & 2 & 24 & 1 \\
\hline Environment & & & 1 & 1 & 3 & 0.8 & 20 & 3 & 56 & 5 & 134 & 7 & 209 & 13 \\
\hline Other & & & & & 2 & 0.6 & 23 & 3 & 29 & 2 & 248 & 12 & 182 & 11 \\
\hline Period Total & 86 & 100 & 100 & 100 & 338 & 100.0 & 663 & 100 & | 1,183 & 100 & 2,047 & 100 & 1,619 & 100 \\
\hline
\end{tabular}

The diversity of issues represented above and now managed by states has created opportunities for private entities willing to work with governments in specific ar-

11 Louis Henkin, Chapter XV: Politics, Values and Functions at the Turn of the Century, in International Law: Politics and Values (Dordrecht: Martinus Nijhoff Publishers, 1995), p. 284.

12 This table was derived from the Comprehensive Statistical Database of Multilateral Treaties (CSDMT), a project of the Honors Programs at Pennsylvania State University at Erie directed by Professor John Gamble. It originated in 1998 with a review of Christian Wiktor, Multilateral Treaty Calendar, 1648-1995 (1998) that Gamble prepared for 
eas. This has happened as states seek to increase their resources and capacities. Power today therefore is not only in the hands of 191 states and governments and the international institutions they have created, but also in those of private entities - multinational corporations, networks of individuals, and nongovernmental organizations (NGOs). ${ }^{13}$

NGOs were particularly effective in areas such as human rights and the environment where states needed political support and capacity "on the ground." Private organizations had an advantage in pursuing these activities within countries that no foreign government could. But the political power and experience gained in securing the promulgation of various new portions of international law continued beyond the enactment of specific obligations to monitoring their ongoing development and implementation. Given their familiarity with the issues and the players, NGOs may in fact be more expert at monitoring and overseeing development of norms than the formal organizations created to do so on an official basis. Robert Keohane and Joseph Nye observed that in addition to the formal governance provided by states and the intergovernmental organizations that they created, governance now also takes place through networks of agents that can be both public and private, that derive credibility from their flexibility and dynamism to address new issues with the fewest start-up costs. ${ }^{14}$

At first glance, one would think that the intensified transborder activity and increased international regulation needed in a globalized world would be a great boost to international law. Instead, what we have seen are increased challenges to the institutional frameworks that were developed to support specific international agreements and obligations. And these challenges to institutions are often perceived as challenges to the international law and legal order that created them. The challenges to these frameworks have come from various levels - from states that act unilaterally, to individuals who organize to demonstrate against the perceived negative effects of globalization, to private terrorist networks that appear dedicated to destroying much of the world order established following World War II because of the power and value structure that the present order represents and supports. States have therefore sought to bolster their ability to govern although through strategic partnerships that may not fit the current formal institutional structure.

Several factors are responsible for this shift:

The increased number of individual rights and responsibilities now recognized by international law some of which can be more effectively addressed by private rather than public entities.

the American Journal of International Law (v. 93, pp. 565-6, 200o). Wiktor and other sources are being used to develop a comprehensive listing of all multilateral treaties from 1500-1999.

13 Paul Kennedy, Dirk Messner, and Franz Nuscheler, eds. Global Trends \& Global Governance (London: Pluto Press, 2002), p. 54.

Robert O. Keohane and Joseph S. Nye, Jr., "Introduction." Governance in a Globalizing World edited by Joseph S. Nye and John D. Donohue (Brookings Institution, 2000), pp. 18-20. 
- The need for private resources to address the complex of issues that make up international law today and the perceived greater agility of the nongovernmental sector to focus on issues particularly in a media contest. ${ }^{\text {is }}$

- The general acceptance that broad public participation is part of good international governance and the technology that not only makes such broad participation possible, but encourages it. As Jessica Mathews wrote: "In every sphere of activity, instantaneous access to information and the ability to put it to use multiplies the number of players who matter and reduces the number who command great authority."16

States seeking such strategic partnerships do so in order to strengthen the likelihood that they will remain the sovereign authorities in their territories even though they no longer "monopolize institutions of global governance, even those that they have formally established, such as the World Bank, International Monetary Fund, and World Trade Organization." ${ }^{17}$

The burgeoning influence of nongovernmental organizations has generated a rich literature. Although the character of their long-term influence is not fully understood, there seems little disagreement that nongovernmental organizations are now a permanent feature of the international political landscape. Fewer than 300 NGOs were represented at the 1972 UN Environment Conference in Stockholm. At the 1992 environment conference in Rio, there were 1,400 NGOs attending the parallel NGO forum. In the area of human rights, at the 1993 UN World Human Rights Conference in Vienna, 248 NGOs were registered with 593 participants. At the Mexico City UN Women's Conference in 1975, 6,000 people attended the NGO forum. In 1985, there were 13,500 individuals registered for the Nairobi UN Women's Conference. And at the 1995 UN Women's Conference in Beijing, over 300,000 individuals attended. ${ }^{18}$

The NGO "cottage industry" has grown to such an extent that an intergovernmental gathering can now be overshadowed by the activities of NGOs. NGOs increasingly have their own venues and activities. But their presence has created an additional source of political pressure that, if linked to other issues or to state sponsors, can develop into a potent political force. The prominence of women's issues on the international agenda today and the adoption of treaties like the Landmines

Robert O. Keohane, "Global Governance and Democratic Accountability," in Taming Globalization: Frontiers of Governance, edited by David Held and Mathias KoenigArchibugi (Cambridge, UK: Polity Press, 2003), p. 131.

Jessica T. Mathews, "Power Shift," Foreign Affairs (January/February 1997), pp. 50-1.

Robert O. Keohane, "Global Governance and Democratic Accountability, in Taming Globalization: Frontiers of Governance, edited by David Held and Mathias KoenigArchibugi (Cambridge, UK: Polity Press, 2003), p. 131.

Ann Marie Clark, Elisabeth J. Friedman, Kathryn Hochstetler, "The Sovereign Limits of Global Civil Society," 51 World Politics (October 1998), p. 9. 
Convention and the Statute for an International Criminal Court, are examples of strategic NGO-state alliances that resulted in highly effective political lobbying. ${ }^{19}$

One study of NGO influence at world conferences concluded that: " $[\mathrm{t}]$ heir importance resides in their role as monitors of governments perceived as unlikely or unable to resolve global problems." ${ }^{20}$ Another observer of UN conference activity wrote that: "The expertise and experience of NGOs are invaluable inputs in decisionmaking processes, and UN conferences have significantly helped legitimize the participation of civil society in international arenas." ${ }^{21}$ The ongoing work of NGOs will depend somewhat on the opportunities states and state institutions (including intergovernmental conferences) provide for direct or parallel activities from NGOs and how able NGOs are to seize these opportunities or to create additional ones. The 1999 demonstrations in Seattle during the World Trade Organization summit and subsequent protests during economic summits are examples of efforts - not all successful - to create new opportunities. NGOs have demonstrated their capacities as political forces and information resources and now draw on a growing coterie of individuals experienced in the related functions of international diplomacy and communication at high profile venues.

Voluntary networks have also demonstrated their power to influence states in the monitoring of state conduct in the treatment of their own citizens. "Principled issue networks," as agents for change in state behavior and even in international standards, are a force for social change that appear to have emerged from the increased level of private transnational activity. Made possible through resources provided by foundations, spurred on by the commitment of individuals, and held together by new technologies, these transnationally linked organizations have had some notable achievements particularly in the protection of human rights..$^{22}$

The technical character of many of the problems requiring international attention and the multi-sector cooperation needed to address them are also part of the explanation for the prominence and recognition of the power of the nongovernmental sector. Technology has also "broken governments' monopoly on the collection and management of large amounts of information." ${ }^{23}$ Events leading up to the signing of the convention to ban the use of anti-personnel landmines (Ottawa Convention, 1997) provided an example of the new power that individuals linked by technology, organized into a political network, and working in alliance

Charlotte Ku (with John King Gamble), "International Law - New Actors and New Technologies: Center Stage for NGOs?" Law and Policy in International Business, Volume 31, No. 2, (Winter 2000), pp. 221-62.

Ann Marie Clark, Elisabeth J. Friedman, Kathryn Hochstetler, "The Sovereign Limits of Global Civil Society," 51 World Politics (October 1998), p. 21.

Jacques Fomerand, "UN Conferences: Media Events or Genuine Diplomacy?” 2 Global Governance (1996), p. 372.

Kathryn Sikkink, "Human Rights, Principled Issue-Networks, and Sovereignty in Latin America, " 47 International Organization (Summer 1993), pp. 411-41.

Jessica T. Mathews, "Power Shift," 76 Foreign Affairs (January/February 1997), p. 57. 
with governments can wield. ${ }^{24}$ The Internet-based campaign spearheaded by Jody Williams gained sufficient recognition for its efforts to win the Nobel Prize for Peace in 1997.

NGO involvement in the drafting of the Statute for the International Criminal Court and its role at the 1998 Rome intergovernmental conference on the ICC shows another kind of NGO role. The two year run-up to the Rome conference gave NGOs the opportunity to organize and to build relationships with UN secretariat staff and other key players in the drafting. This careful cultivation by the NGO coalition of opportunities for participation and influence paid off. At the end of the process, one NGO participant concluded that: "Governments and the team from the [UN] Office of Legal Affairs came to accept NGOs as indispensable consultants and worthwhile advocates." ${ }^{25}$ That there may be as many ways for NGOs to be influential as there are issues does not diminish the general conclusion that they have become a political force on the international scene that is not likely to vanish.

Even decades ago, the kind of "people power" generated by Helsinki Watch, Charter 77, Solidarity and other nongovernmental groups eventually created pressures for human rights and an end to the Cold War from within the Warsaw Pact countries themselves. Yet, while it seems clear that the public sector can no longer function effectively without the cooperation and participation of the private sector and the involvement of individual citizens, it remains true that the private sector cannot solve all problems without the infrastructure and coordination that states and international institutions provide. The 1975 Helsinki Final Act of the Conference on Security and Cooperation in Europe was, after all, an intergovernmental agreement that fostered an important "human dimension" through its system of follow-up conferences. The follow-up conferences also provided opportunities for NGOs seeking to liberalize the political institutions of the Warsaw Pact countries to gain political legitimacy and for their leaders to gain confidence in political activism and in the support of the international media for their efforts. The entire process fostered nothing less than a quiet and largely bloodless revolution. ${ }^{26}$

These examples show the promise of such strategic partnerships. Indeed, they might even be viewed as essential in today's globalized environment. UN Secretary-General Kofi Annan expressed such views in his millennium report, "We the Peoples: The Role of the United Nations in the 21st Century." He wrote:

24 See Stephen Greene, "A Campaign to Sweep Away Danger," 60 Chronicle of Philanthropy (20 October 1997). See also Richard Price, "Transnational Civil Society Targets Land Mines," 52 International Organization (Summer 1998), pp. 613-44.

25 Fanny Benedetti and John L. Washburn, "Drafting the International Criminal Court Treaty: Two Years to Rome and an Afterword on the Rome Diplomatic Conference," 3 Global Governance (1999), p. 25.

26 See Thomas Buergenthal, "CSCE Human Dimension: The Birth of a System," in Collected Courses of the Academy of European Law (1992). 
... while the post-war multilateral system made it possible for the new globalization to emerge and flourish, globalization, in turn, has progressively rendered its designs antiquated. Simply put, our post-war institutions were built for an inter-national world, but we now live in a global world. ${ }^{27}$

Annan further noted that: "We must also adapt international institutions, through which states govern together, to the realities of the new era. We must form coalitions for change, often with partners well beyond the precincts of officialdom." ${ }^{28}$ But the ad hoc and selective character of these partnerships have caused concern about the effectiveness and reliability of such arrangements as durable pillars of global governance.

\section{The Multiple Forms of Legal Obligation}

Further adding to the complexity of the contemporary governing environment are the forms legal obligations can now take. Although the reasons for accepting obligations under international law may vary, a growing body of empirical work shows that both formal and informal obligations can influence behavior. ${ }^{29}$ In an illuminating essay on the emergence of soft law, Christine Chinkin points to the challenges posed by the concept to global governance, but nevertheless concludes that it be maintained for the contribution that it can make. She writes:

There is a wide diversity in the instruments of so-called soft law which makes the generic term a misleading simplification. Even a cursory examination of these diverse instruments inevitably exposes their many variables in form, language, subject matter, participants, addressees, purposes, follow up and monitoring procedures. These variables, coupled with the inherent contradictions in any concept of soft law, highlight the challenges presented to the structure and substance of the traditional legal order by the increasing use of soft law forms. ${ }^{30}$

Why, then adopt such a potentially confusing form of obligation? There are a number of reasons:

Kofi A. Annan, "We the Peoples: The Role of the United Nations in the $21^{\text {st }}$ Century," (New York: United Nations Office of Public Information, 2000), p. 11.

28 Kofi A. Annan, "We the Peoples: The Role of the United Nations in the $21^{\text {st }}$ Century," (New York: United Nations Office of Public Information, 2000), p. 7.

29 See Dinah Shelton, ed., Commitment and Compliance: The Role of Non-Binding Norms in the International Legal System (Oxford: Oxford University Press, 200o); Antonia Handler Chayes and Abram Chayes, The New Sovereignty (Cambridge: Harvard University Press, 1995), Edith Brown Weiss and Harold K. Jacobson, Engaging Countries: Strengthening Compliance with International Environmental Accords (Cambridge, MA: The MIT Press, 1998). 
- It is a form that can move domestic issues into the international realm for example as seen in commodity agreements or marketing specific products like breast milk substitutes. ${ }^{32}$

- It is a vehicle to link international law to private entities regulated principally by domestic law like individuals and transnational corporations. ${ }^{32}$

- It may provide states a way to come to terms without the political difficulty of undertaking a full scale legal obligation. Examples of such important "political" agreements are the Yalta agreement of 1945 and the Helsinki Final Act of 1975.

- Different forms of obligation may be combined as can be seen in environmental law-making where a framework convention can be followed by protocols that generate soft law or practice to supplement the original text. Dinah Shelton explained that: "Typically, the framework convention establishes a structure for further co-operation between the parties through monitoring and implementation procedures, exchanging data, and facilitating regulation. They also permit ease of response to changed scientific knowledge and circumstances." ${ }^{33}$

The specific governance problem created by soft law on the international level is how to identify it as an international obligation, i.e. can it be considered to be jus cogens or customary international law?34 Despite the challenges, Professor Chinkin observed that soft law is also a phenomenon that is here to stay because international affairs have outpaced the ability of the traditional law-making machinery "through international organizations, specialized agencies, programmes, and private bodies that do not fit the paradigm of Article 38(1) of the Statute of the ICJ." ${ }_{35}$ At its best, soft law can bridge the gap "between the formalities of law-making and the needs of international life by legitimating behavior and creating stability." On the other side of the ledger, soft law can produce incoherent standards and multiple legal regimes. On balance though, Professor Chinkin argues favorably for soft law as a means to "allow for the incorporation of conflicting standards and goals and provide States with the room to manoeuvre in the making of claims and counter-

C.M. Chinkin, "The Challenge of Soft Law: Development and Change in International Law, 38 International and Comparative Law Quarterly (October 1989), p. 853. C.M. Chinkin, "The Challenge of Soft Law: Development and Change in International Law, 38 International and Comparative Law Quarterly (October 1989), p. 854.

33 Christine Chinkin, "Normative Development in the International Legal System" in Dinah Shelton, ed., Commitment and Compliance: The Role of Non-Binding Norms in the International Legal System (Oxford: Oxford University Press, 2000), p. 27.

34 C.M. Chinkin, "The Challenge of Soft Law: Development and Change in International Law," 38 International and Comparative Law Quarterly (October 1989), p. 857.

35 Christine Chinkin, "Normative Development in the International Legal System" in Dinah Shelton, ed., Commitment and Compliance: The Role of Non-Binding Norms in the International Legal System (Oxford: Oxford University Press, 200o), p. 42. 
claims." ${ }^{\prime 36}$ We may also find that over time, soft law may harden through practice or through implementation by international or national institutions that are hard governing or regulatory regimes.

International law's challenge to global governance is therefore to provide effective regulation and problem-solving for the newly enlarged international and transnational political space that has been one of the great successes of the twentieth century. As Mary Kaldor observes, the elements of civil society - voluntary associations, movements, parties, and unions for example, enable individuals "to act publicly. ${ }^{{ }^{37}}$ But, what about the public institutions charged with important governance functions? In many respects, these units of global governance seem out of step with the world we now live in. Several reasons help explain why this has occurred:

- International law and the institutions it creates are state-based and therefore generally voluntary. This makes undertaking change difficult whenever a state and even more so if an important state's interest are affected by such change. A prominent example is the difficulty now faced to revise the permanent membership of the United Nations Security Council. None of the privileged states that are presently permanent members would willingly give up that privilege. On the other hand, the very voluntary character of these institutions may also make it difficult to regulate or to control powerful states that do not wish to be controlled. Examples of this are the failure of France and Germany to comply with the deficit levels set by the Maastricht Treaty for countries using the euro and the US use of force in Iraq in 2003.

- The capacities of international institutions are limited and remain at the mercy of member states that may withhold resources for programs and operations as may suit these instincts rather than the objectives of the institutions or the programs. See, for example, the sobering conclusion of a report prepared for Congress by the General Accounting Office concluding that it may be difficult to use any results-oriented measures in state-building because donor states may pull out regardless of whether objectives have been met or not. ${ }^{38}$

- That the ability to respond to new situations can be further constrained by the need to achieve consensus among a wide range of views and interests. Indeed, the perceived need to put the most positive face on a situation in order to avoid political embarrassment was thought to be a problem for adequate preparation and training for troops assigned to UN peace-building operations. ${ }^{39}$

36 C.M. Chinkin, "The Challenge of Soft Law: Development and Change in International Law, 38 International and Comparative Law Quarterly (October 1989), p. 866.

37 Mary Kaldor, "The idea of global civil society", 79 International Affairs (2003), p. 585.

38 See U.S. General Accounting Office, "U.N. Peacekeeping: Transition Strategies for Post-Conflict Countries Lack Results-Oriented Measures of Progress," (September 2003).

39 See UN Report of the Panel on United Nations Peace Operations (August 2000). 
- That the effectiveness of international institutions may be constrained by the preceding three factors causing states to reduce further support because of a concern that the institution is no longer effective and can no longer serve their interests. This was clearly the message delivered by U.S. President George W. Bush when he addressed the United Nations General Assembly on September $12,2002 .{ }^{40}$

- And finally that international institutions may not be regarded as accountable for their conduct because officials serving in these institutions are too far removed from the political processes that could bring about their dismissal.

Reflecting this development, John Rawls envisions a more explicit role for civil society as he writes: "... it may turn out that there will be many different kinds of organizations subject to the judgment of the Law of Peoples and charged with regulating cooperation among them and meeting certain recognized duties." ${ }^{21}$ But what does such a governing system look like and what role might international law play in such a diffused and only partially institutionalized system?

\section{Elements of a Multilayered and Mixed System of Governance}

As the above suggests, international law and global governance have become multilayered in part because political power has become multilayered. David Held noted that: [Political power] became diffused below, above and alongside the nationstate." ${ }^{42}$ To address this, the state has undertaken informal governing partnerships that may not be readily identifiable, accountable or even long-lasting. Nevertheless, international lawyers should readily recognize that "norms do not operate automatically but through the activities of agents in networks." 43 These networks and ad hoc arrangements do not replace the formal institutionalized governing mechanisms such as the UN system, but exist alongside it.

International lawyers have long recognized the partially institutionalized character of international law and note it as a fundamental difference from domestic law when describing the nature of international law. A great effort was made through the nineteenth and twentieth centuries to institutionalize international legal activities at the international level. The effort began with the regulatory unions of the nineteenth century that were the predecessor organizations of many of the UN's specialized agencies today. The effort continued with the establishment of the League of Nations and the United Nations to provide a centerpiece for inter-

40 George W. Bush, Address to the UN General Assembly, September 2002.

41 John Rawls, The Law of Peoples (Cambridge: Harvard University Press, 1999), p. 36.

42 David Held, "From Executive to Cosmopolitan Multilateralism," in Taming Globalization: Frontiers of Governance, edited by David Held and Mathias Koenig-Archibugi (Cambridge, UK: Polity Press, 2003), p. 180.

Robert O. Keohane and Joseph S. Nye, Jr., "Introduction." Governance in a Globalizing World edited by Joseph S. Nye and John D. Donohue (Brookings Institution, 2000), p. 
national activity. The organizations were set up with a plenary body, a governing council, a secretariat and a court. The United Nations added economic and social concerns to its principal responsibilities and dedicated one of its six principal organs to those responsibilities.

The existence of this universal organization, however, did not quell the effort to develop regional organizations in the European Union and in less integrationist efforts like the Organization of American States or the African Union. And as we now move into the twenty-first century, we see that the partially institutionalized character of international law may in fact provide an advantage for its ongoing effectiveness by making it possible to work in a number of institutional settings. This means that states can join forces with each other, with sub-national components of states, with NGOs or with intergovernmental organizations in order to carry out their obligations. What may be presently lacking in this mixed system of governance is cohesion and coordination among all possible governing units and processes. Within such a non-hierarchical and partially institutionalized structure, such cohesion and coordination could be provided by a common and broad commitment to governance on the basis of respect for law. Three elements of such governance already exist and are described below. Each is tied to an institutional framework although it may not be an international one. The more institutionalized and formal framework may in fact be a national one working informally at the transnational or international level. At the same time, the transnational and international may offer the national something that it does not have operating alone - the ability to reach outside its borders. Given the globalized character of many regulatory problems today, this ability to reach beyond one's own borders and to be able to count on the assistance of counterparts in other countries is one of the incentives for cross border cooperation.

\section{Transnational Networks: Governing through Transgovernmentalism}

More than 20 years ago in 1983, Harold Jacobson wrote:

What we have ... is a global political system that is already complex and growing even more complex. Nation-states retain sovereignty and consequently remain the principal actors in international politics. But all states are enmeshed in complex webs of international organizations, both governmental and nongovernmental, and their societies, rather than being sealed from one another, are linked by growing transnational connections. Although political authority continues to be centered in governments of nation-states, in reality it is widely dispersed. With respect to countless issues, to be effective governments must act together, but different issues elicit cooperation by different combinations of states. States entangled in webs of international organizations is the proper simile to describe the contemporary global political system, and international organizations, both IGOs and INGOs, are best seen as sophisticated communication devices, instruments for transmitting and relaying messages and coordinating actions. The global political system continues to consist of multiple sovereign centers 
of decision making, but effective power is increasingly being organized in a non-hierarchical manner. ${ }^{44}$

Given the effects of globalization, this view of a non-hierarchic multi-centered political system in which both states and international institutions play roles in governance certainly seems an accurate depiction of the world today.

Fifteen years later in 1997, reflecting on similar issues, Anne-Marie Slaughter published "The Real New World Order," where she concluded that the international governance model of a multipurpose international institution like the United $\mathrm{Na}$ tions at its center had built in limits because "it requires a centralized rule-making authority, a hierarchy of institutions, and universal membership."45 In place of this, she observes that governance has moved into a transgovernmental order of "courts, regulatory agencies, executives, and even legislatures...networking with their counterparts abroad, creating a dense web of relations ...." ${ }^{46}$ She argues that this can provide a much more expandable and flexible system of governance than is available through the classic system of states and intergovernmental organizations.

Transgovernmental governance works by adopting "rules concerning issues that each nation already regulates within its borders: crime, securities fraud, pollution, tax evasion," for example. Examples of such networks are the Basle Committee on Banking Supervision, the International Organization of Securities Commissioners, and the International Association of Insurance Supervisors. Another form of transgovernmental governance occurs through bilateral and plurilateral regulatory agreements in the form of Memoranda of Understanding and Mutual Legal Assistance Treaties. ${ }^{47}$ The incentive for national regulators to use these transgovernmental rules is the transnational nature of many of the issues they now address. And working transnationally provides regulators the benefits of coordinating actions with other countries..$^{48}$ The advantage for states is the flexibility and decentralization that this approach provides. The shortcoming is in any formal accountability or oversight of such actions until or unless a conflict occurs.

An example of where a country's security may be very much dependent on activities outside that country is the effort to address the post September 11, 2001 security needs in the United States. Dean Slaughter explained:

Harold K. Jacobson, Networks of Interdependence: International Organizations and the Global Political System, $2^{\text {nd }}$ edition (New York: Alfred A. Knopf, 1984), p. 387.

Anne-Marie Slaughter, "The Real New World Order," 76 Foreign Affairs (September/ October 1997), p. 183.

Anne-Marie Slaughter, "The Real New World Order," 76 Foreign Affairs (September/ October 1997), p. 184.

See Anne-Marie Slaughter, "Governing through Government Networks," in Michael Byers, ed., The Role of Law in International Politics (Oxford: Oxford University Press, 2000), pp. 177-205 and Anne-Marie Slaughter, A New World Order (Princeton: Princeton University Press, 2004).

Anne-Marie Slaughter, "The Real New World Order," 76 Foreign Affairs (September/

October 1997), p. 191-2. 
Public attention focused on military cooperation, but the networks of financial regulators working to identify and freeze terrorist assets, of law enforcement officials sharing vital information on terrorist suspects, and of intelligence operatives working to preempt the next attack have been equally important. Indeed, the leading expert in the "new security" of borders and container bombs insists that the domestic agencies responsible for customs, food safety, and regulation of all kinds must extend their reach abroad, through reorganization and much closer cooperation with their foreign counterparts....Networked threats require a networked response. ${ }^{49}$

For international law, this approach means a "nationalization of international law." In this vision, "[r]egulatory agreements between states are pledges of good faith, that are self-enforcing, in the sense that each nation will be better able to enforce its national law by implementing the agreement if other nations do likewise. Laws are binding or coercive only at the national level. Uniformity of result and diversity of means go hand in hand, and the makers and enforcers of rules are national leaders who are accountable to the people." ${ }^{50}$ This is clearly a piece of the contemporary governance picture although its operation and implications for a common respect for the law may still be developing.

\section{Transnational Legal Process and Legal Internalization}

Another approach that relies on national systems to implement international law is Harold Koh's view of transnational legal process. He sees the process as threefold: interaction, interpretation, and internalization. ${ }^{51}$

Legal internalization occurs when an international norm is incorporated into the domestic legal system through executive action, judicial interpretation, legislative action, or some combination of the three....Judicial internalization can occur when domestic litigation provokes judicial incorporation of human rights norms either implicitly, by construing existing statutes consistently with international human rights norms, or explicitly, through what I have elsewhere called "transnational public law litigation." Legislative internationalization occurs when domestic lobbying embeds international law norms into binding domestic legislation or even constitutional law that officials of a noncomplying government must then obey as part of the domestic legal fabric. ${ }^{52}$

49 Anne-Marie Slaughter, A New World Order (Princeton: Princeton University Press, 2004), pp. 1-2.

so Anne-Marie Slaughter, “The Real New World Order," 76 Foreign Affairs (September/ October 1997), p. 192.

51 Harold Honjuh Koh, "Why Do Nations Obey International Law?" 106 The Yale Law Journal (June 1997), p. 2649.

52 Harold Honjuh Koh, "Why Do Nations Obey International Law?" 106 The Yale Law Journal (June 1997), p. 2657. 
Such internalization has given rise to a visceral backlash against the use of foreign law in U.S. courts. The editors-in-chief of The American Journal of International Law in an introduction to the "Agora: The United States Constitution and International Law" put it this way:

On the docket of the United States Supreme Court in 2004 is a substantial cluster of cases at the intersection of constitutional and international law. In the previous two Supreme Court Terms, the Court had adverted to sources of law and practice outside the United States, in its treatment of constitutional claims involving the death penalty and same-sex relationships. The apparent willingness of the Court to consider international and foreign authorities in reaching its conclusions on contested issues of international law has raised to new prominence the debate over the relationship between constitutional and international law. It is not yet clear whether the new (or newly rediscovered) interest of the Court in international sources presages a long-term trend towards a more cosmopolitan constitutional jurisprudence. On the assumption that this represents more than a passing fad, advocates before the Court in the current Term-for example, in the cases involving the "enemy combatant" detainees at Guantanamo Bay-have vigorously pressed arguments concerning international and foreign law in connection with the constitutional issues at stake. The Court's acceptance of quite a few cases raising a mixture of international and constitutional questions for decision in 2004 may signal that the Court is preparing for a new era of engagement with legal developments external to the United States, or, alternatively, that it seeks to limit (or in any event to delimit) the relevance of such developments for the U.S. legal

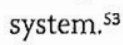

The tenor of the above comment suggests that the process of internalization is underway. And indeed, while controversy may rage on the appropriate use of international law at the level of the U.S. Supreme Court, the Chief Justice of the Supreme Court of Texas noted that:

... both state courts and federal courts have, since the inception of the Republic, applied and developed international law. The constitutional framers could have structured the government so that most of this authority would lodge in the federal system, but they declined to do so. Congress could have used the jurisdictional grant in the Constitution to place most international questions in federal court, but it has likewise declined to do so. Thus the state courts remain vital partners in the interpretation and application of both formal and customary international law. ${ }^{54}$

Lori Fisler Damrosch and Bernard H. Oxman, "Editors' Introduction to Agora: The United States Constitution and International Law," 98 American Journal of International Law (January 2004), p. 42.

54 Thomas R. Philips, "State Supreme Courts: Local Courts in a Global World," 38 Texas International Law Journal (Special 2003), p. 558. 
Justice Philips further predicted that in certain areas, international cases would increase and particularly for state courts because of the nature of those cases in the criminal and family law areas that have traditionally been the province of state courts. At the same time, Justice Phillips noted that there may be an overall decline of international cases as mediation and extra-judicial proceedings are used more frequently even for family law and trade matters. But, he concludes that as long as courts retain a role in handling international matters, state courts in the United States will be among them..$^{55}$

A special example of internalization comes from the European Union. AnneMarie Slaughter and Walter Mattli described this:

Until 1963 the enforcement of the Rome treaty [the constituent treaty of the European Union], like that of any other international treaty, depended entirely on action by the national legislatures of the member states of the community. By 1965, a citizen of a community country could ask a national court to invalidate any provision of domestic law found to conflict with certain directly applicable provisions of the treaty. By 1975 , a citizen of an EC country could seek the invalidation of national law found to conflict with self-executing provisions of community secondary legislation, the "directives" to national governments passed by the EC Council of Ministers. And by 1990, community citizens could ask their national courts to interpret national legislation consistently with community legislation in the face of undue delay in passing directives on the part of national legislatures. ${ }^{56}$

The pioneering work in the development of a regional human rights system that the jurisprudence of the European Court of Human Rights represents is a further important example of the interactions between extra-national and national systems of law.

One of the more sweeping recent examples of incorporation is that of the British incorporation of the European Convention on Human Rights into its domestic law that "marks a dramatic shift in how individual rights are conceptualized under British law ... The Human Rights Act, which puts courts and other public authorities under a positive duty to 'give effect' to the rights enumerated in the European Convention in their day-to-day activities, marks a shift in the perception of civil liberties from residual freedoms to positive rights. ${ }^{57}$

States undertake such dramatic changes because of the advantages to being part of a regional system. It may be worth remembering that the genesis of the European human rights system was the desire to create normative and institutional safeguards against the atrocities and genocide committed by Nazi Germany. These safeguards

Thomas R. Philips, "State Supreme Courts: Local Courts in a Global World, 38 Texas International Law Journal (Special 2003), pp. 564-5.

56 Anne-Marie Burley (Slaughter) and Walter Mattli, "Europe Before the Court: A Political Theory of Legal Integration," 47 International Organization (Winter 1993), p. 42.

Douglas W. Vick, "The Human Rights Act and the British Constitution," 37 Texas International Law Journal (2002), p. 330. 
called for transnational oversight and monitoring of national actions as represented by the investigations of the European Commission on Human Rights and subsequent adjudication before the European Court of Human Rights. The system, however, does not mandate homogeneity. Indeed, it provides for a structure in which differences can be recognized and accepted as a tolerable difference that does not stand in the way of the protection of human rights that is the Convention's primary objective.

\section{Global Governance through Coordination}

Perhaps one of the most serious apparent inadequacies of the present governance system is in the area of the use of force. Whether it has been understanding the appropriate normative approach to the concept of humanitarian intervention or of preemptive action in the face of some other perceived threat, the UN Charter system dealing with the use of force has come under increasing stress since the end of the Cold War in $1989 . .^{58}$ But, if the current structure of international institutions does not effectively address these questions, does this necessarily mean the return to a self-judging and unregulated international security system?

Implicit in that question is the assumption that without international regulation by international institutions, state behavior is essentially unregulated. Such a conclusion would overlook the considerable number of national safeguards that can exist at the state level to protect against the wanton loss of lives and resources through military operations that do not serve a state's interests. This is relevant to international regulation because the international system also tries to eliminate the unregulated use of force in order to minimize destruction and loss of life and as such, is consistent with the purposes of many national safeguards.

National safeguards are not a substitute for international regulation, but when international regulation fails or proves inadequate, regulation can and does move to the national level. National safeguards further come in two forms - the formal and the informal. Formal safeguards are found in constitutions and national institutions such as legislatures, courts, and budgets. ${ }^{59}$ Informal safeguards operate through political culture and public opinion. ${ }^{60}$ The effectiveness of these safeguards varies widely depending on the strength of the domestic political system including whether it is democratic and how open it is to public debate or not.

58 See Boutros Boutros-Ghali, An Agenda for Peace (New York: United Nations Department of Public Information, 1995).

59 For examples of constitutional restraints, see Lori Fisler Damrosch, "The interface of national constitutional systems with international law and institutions on using military forces: changing trends in executive and legislative powers," in Charlotte Ku and Harold K. Jacobson, Democratic Accountability and the Use of Force in International Law (Cambridge: Cambridge University Press, 2003), pp. 39-60.

60 For examples of such political factors, see Karen A. Mingst, "Domestic political factors and decisions of use military forces," in Charlotte Ku and Harold K. Jacobson, Democratic Accountability and the Use of Force in International Law (Cambridge: Cambridge University Press, 2003), pp. 61-80. 
National political and legal processes may also take on more prominent roles in cases when international law appears inadequate to address particular circumstances. When existing international standards and structures are under stress, national debate and political process may help to fill the gap and set the criteria for action as well as the limits for such operations. ${ }^{61}$ The closer the use of military force gets to war, the more will national systems play a role in the decision to take part in such operations and in overseeing their operation. This process in turn contributes to shaping both the practice and scope of international action. As the Panel on UN Peace Operations concluded in 2001: "[T] he United Nations does not wage war. Where enforcement action is required, it has consistently been entrusted to coalitions of willing States, with the authorization of the Security Council acting under Chapter VII of the Charter." ${ }^{22}$

The interactions of international and domestic decision-making processes have been well recognized in international organization studies like Robert Cox and Harold Jacobson who concluded in their classic study of decision-making, The Anatomy of Influence, that the significance of international organizations is better judged "not as how independent they are of states, but how far they involve the effective policy-making process of governments." ${ }^{13}$ What debates over the 2003 war in Iraq now tell us is that involving the effective policy-making processes of national governments is no longer adequate in all cases. National decision-making processes require certain levels of legitimacy that may now include appropriate international authorization and standards.

Another example of the current influence of international institutions is the generalized move towards multilateralism as the basis for foreign policy. This view has been most publicly advanced by two of the principal powers of the European Union, France and Germany. The French view has been described as stemming from:

... its opposition to any kind of domination or hegemony of the world scene by a single state; France has a preference for multipolarity, of which the Security Council is an institutional component and safeguard. The UNSC remains the only international institution able to legitimize the use of force. In the Kosovo crisis...France was keen to find a legal basis for action by NATO in the previous resolutions of the Security Council, even if this justification was difficult to sustain. When urgency prevents such authorization beforehand, France still insists on having the Security Council ratify a posteriori an intervention. The continuous efforts made by France to get the UNSC involved in the Kosovo crisis, after the military intervention started in the spring of 1999, derived directly from this opposition to ad hoc multipolarity. ${ }^{64}$

61 See Adam Roberts, "NATO's 'Humanitarian War," Survival (Autumn 1999), p. 107.

62 UN Report of the Panel on United Nations Peace Operations (August 2000).

63 Robert W. Cox and Harold K. Jacobson, The Anatomy of Influence: Decision Making in International Organization (New Haven: Yale University Press, 1974), p. 428.

64 Yves Boyer, Serge Sur, and Olivier Fleurence, "France: Security Council legitimacy and executive primacy," in Charlotte Ku and Harold K. Jacobson, Democratic Accountabil- 
And even in the United States, poll after poll showed that Americans prefer that their government work under a UN or other multilateral mandate whenever possible. Those surveyed, however, also indicated that they looked for effectiveness in these mandates. ${ }^{65}$ The coordinated approach therefore meshes the international and national with increased prominence of the international at certain levels of activity like the initial authorization of the use of force.

\section{Conclusion: Imagining a Multilayered System of Governance}

The pressures on international institutions created by the growth in international law in the twentieth century coupled with the economic, social, and political forces collectively known as globalization have produced gaps in global governance. These gaps have created concern about the viability of any global order if individual states begin to act on their own and revert to the voluntarist system of international relations that existed prior to the twentieth century. But as we review some of the innovations that have developed to increase the capacity of states and international institutions to regulate and to manage the issues they face, the future of global governance may not be as dire as one might imagine. States are seeking ways to address problems and to manage issues in ways that can also contribute to global governance over time.

The ability of these new governance channels to operate in a coordinated way, however, will depend in part on the ability of international lawyers to think in a global and transnational way. In other words, we must begin to develop an awareness of states as part of a globalized system of governance system that does not consist only of international institutions. States may contribute to global governance by working with each other, and with the private and NGO sectors, not only through international institutions. The means by which states contribute to governance may differ. They include informal relations, incorporation, and coordination to pursue common goals, implement international standards, and carry out international obligations.

This is not a return to some form of early Westphalianism where multiple units compete without regard to the general order. It is rather recognition of a complex governing system in which elements of global governance act in less formal and less hierarchical ways in order to increase the flexibility and speed with which they can address new developments. Even though the existing system of institutionalized global governance may be under stress, this does not mean a return to unregulated state behavior. But if states cannot be made to act in the collective interest through international institutions, how can they be expected to do so when regulating activities through informal structures and processes? This is where some

ity and the Use of Force in International Law (Cambridge: Cambridge University Press, 2003), p. 287.

65 Chicago Council on Foreign Relations, Worldviews 2002 Survey of American and European Attitudes and Public Opinion on Foreign Policy: American Public Opinion \& Foreign Policy available at htto://www.worldviews.org/index.html. 
broad general principles with a common objective of establishing a juridical order with a common respect for law might be helpful. Such principles might include:

1. A commitment to a rule-based, but not necessarily institutionalized international system that is sufficiently robust to address the myriad challenges and issues that now face states and that is effective in addressing a state's interests and responsibilities.

2. A commitment to creating the conditions that will compel states to close the economic, political, and social gaps that presently exist within societies and throughout the world. A rule-based system cannot work unless the rules appear to provide all with equal opportunity and the means to pursue interests within the system.

3. A commitment to effective management of transnational problems through strategic public and private sector partnerships.

4. A commitment to "consultation and active assistance" in the place of "unilateral action and noninterference."66

5. A commitment to broad participation by all who are affected by an issue.

The effective operation of a multilayered system of governance will require the commentary and insight of jurists around the world. Article 38, paragraph 1 of the Statute of the International Court of Justice recognizes such a function since it includes "judicial decisions and the teachings of the most highly qualified publicists of the various nations, as subsidiary means for the determination of the rules of law." This will ensure effective interaction of the disparate elements of a global governance system.

This multilayered system is already in operation, but perhaps not yet well understood by international lawyers. It is one where additional forms of governance, some of which might be ad hoc, will work alongside existing international institutions to carry out international obligations. This will provide greater flexibility and increase the resources available to address problems as they arise and provide a means to harness global resources for local problems. Globalization has created a world where local problems and issues have far reaching and sometimes global effects. Globalization has also provided the means for broad participation in the resolution of such issues. The measure of international law's success will be its effectiveness in addressing issues and creating the means to formulate solutions. International lawyers will need to think and work beyond existing institution-centered concepts to encompass a wider variety of processes and agents to give life and meaning to international legal obligations. Present conditions provide international law with an opportunity to take center stage as the hub of a multilayered and multidimensional system of global governance.

66 Anne-Marie Slaughter, A New World Order (Princeton: Princeton University Press, 2004), p. 30. 